\title{
Seasonal variations in the energy budget of Elliot's pheasant (Syrmaticus ellioti) in cage
}

\author{
Ying LUO ${ }^{1}$, Tai-Lin YU ${ }^{2, *}$, Cheng-Ming HUANG ${ }^{3, *}$, Tong ZHAO ${ }^{2}$, Han-Hua LI ${ }^{2}$, Chang-Jian LI ${ }^{1}$ \\ 1. Department of Life Science and Chemistry, Hunan University of Science and Engineering, Yongzhou 425199, China; \\ 2. College of Life Science, Guangxi Normal University, Guilin 541004, China; \\ 3. Institute of Zoology, the Chinese Academy of Science, Beijing 100101, China
}

\begin{abstract}
This study aimed to discuss the energy budget of Elliot's pheasant Syrmaticus ellioti in different seasons, with life and health, good growth and normal digestion of Elliot's pheasant as the tested objects, The energy budget of Elliot's pheasant was measured by daily collection of the trial pheasants' excrement in the biological garden of Guangxi Normal University from March 2011 to February 2012. The results showed that the gross energy consumption, metabolic energy and excrement energy varied by season, increasing as temperature decreased. There was significant difference in gross energy consumption, metabolic energy, excrement energy between adults and nonages. There was also a trend that food digestibility of pheasants increases as temperature increases. In the same season, the food digestibility of adults was better than that of nonages. Throughout spring, summer, autumn and winter, the metabolic energy of 4-year adults were $305.77 \pm 13.40 \mathrm{~kJ} / \mathrm{d}, 263.67 \pm 11.89 \mathrm{~kJ} / \mathrm{d}, 357.23 \pm 25.49 \mathrm{~kJ} / \mathrm{d}$ and $403.12 \pm$ $24.91 \mathrm{~kJ} / \mathrm{d}$, respectively, and the nonages were $284.86 \pm 17.22 \mathrm{~kJ} / \mathrm{d}, 284.66 \pm 15.16 \mathrm{~kJ} / \mathrm{d}, 402.26 \pm 31.46 \mathrm{~kJ} / \mathrm{d}$ and $420.30 \pm 31.98$ $\mathrm{kJ} / \mathrm{d}$, respectively. The minimum metabolic energies were $247.65 \pm 21.81 \mathrm{~g}, 265.86 \pm 26.53 \mathrm{~g}$, respectively for each group, detected between 4-year adults and 1-year nonages. Further study is needed to determine whether $29.6 \mathrm{C}$ is the optimal temperature for the Elliot's pheasant.
\end{abstract}

Keywords: Elliot's pheasants; Energy budget; Seasonal variations

Elliot's pheasant Syrmaticus ellioti is a vulnerable species peculiar to China (Baillie et al, 2004), mainly distributed across the eastern hilly sub-region in central China, including Zhejiang, Anhui, Fujian, Jiangxi, Hubei, Hunan, Guangdong, and Guangxi provinces (Delacour, 1977; Ding \&Zhu, 1989; Li, 1996; Ding, 1998). Mainly inhabiting rugged mountains and jungle of valleys at an altitude of 200-1 $500 \mathrm{~m}$, more commonly in mixed conifer-broad leaved forests, Elliot's pheasant can also be found in dense bamboo and forest understory. Elliot's pheasant is omnivorous, mainly eating plant leaves, stems, buds, flowers, fruits, seeds and other crops, but also insects and other animals (John et al, 2000). Due to chronic deforestation, burning and vegetation reclamation, agricultural encroachment and the stress of hunting among other factors, Elliot's pheasant is approaching of the serious loss, fragmentation and degeneration of its habitat (Ding et al, 2000). According to the survey on typical habitat of Elliot's pheasant in Kaihua County, Zhejiang in 1984, the population density of Elliot's pheasant was $3.5 / \mathrm{km}^{2}$ in summer and $6.9 / \mathrm{km}^{2}$ in winter ( $\left.\mathrm{Li}, 1985\right)$.

Since the 1980s, domestic researchers have studied the field ecology of the form, distribution, living habits, activity regularity, breeding habits, habitat types of Elliot's pheasant, and learned about the wild pheasant populations (Li, 1985; Long, 1985; Ding \& Zhu, 1988). Since the 1990s, the " $3 \mathrm{~S}$ " technologies were used widely used for the study of the pheasant's inhabiting features, selection mechanism as well as habitat type and feature (Ding et al, 1996, 2001; Shi \& Zheng, 1997), habitat vegetation fragmentation (Ding et al, 2000) and activity

Received: 11 JUNE 2011; Accepted: 01 August 2012

Foundation items: National Natural Science Foundation of China (31160426; 30560023); the Projects of Science and Technology Office of Hunan (2011FJ3071).

"Corresponding authors, E-mail: yutail@163.com; cmhuang@ioz.ac.cn 
area (Cai et al, 2007; Xu et al, 2007). Researchers have likewise studied more recently the genetic diversity, genetic structure and genetic flow on the basis of mitochondria DNA in Elliot's pheasant (Jiang et al, 2005a, 2005b, 2007). However, despite recent progress, the previous studies seldom deal with the energy budget and feed intake of Elliot's pheasant (Luo et al, 2007, 2011), a significant feature for studying the variation of energy ecology of Phasianidae that live in the subtropical shrub ecosystems.

The birds' capabilities of gaining energy depend on food digestibility and energy acquisition from food in limited time, or more succinctly, only the available energy in an environment is turned into chemical energy before it can be used ( $\mathrm{Lu}, 1991)$. Food is the basis adaptation to environmental surroundings and maintaining their lives, Elliot's pheasant can get the energy from the everyday food, helping to keep their normal day to day activities in check and build their own bodies. Studying the energy intake of Elliot's pheasant in cage will greatly contribute to grasping their food digestibility, and inferring the energy demand of maintaining wild Elliot's pheasant, while also laying the basis of the population energy ecology and the environmental carrying capacity needed for successful reintroduction of Elliot's pheasant, At the same time, this study also provides a scientific foundation for more adequate management of Elliot's pheasant in captivity. Between March 2011 and February 2012, we researched the different seasonal energy intake of Elliot's pheasant at different age in the Breeding Base of Endangered Pheasants, Guangxi Province - the Biological Garden of Guangxi Normal University.

\section{MATERIALS AND METHODS}

\section{Animals}

According to the mating system of the wild Elliot's pheasant ( 1 male, 2 or 3 females), we selected 12 Elliot's pheasants of different ages, that were alive and healthy, good growth and normal digestion from the Biological Garden of Guangxi Normal University in March 2011, 6 of them were 4 -year old ( 2 males, 4 females), and once bred. The number of other group of trial pheasant were also 6 ( 2 males, 4 females), which be hatched in May 2010. Since Elliot's pheasant have strong stress, in order to make the trial pheasants adapt to the environment of separate feeding, the pre-experiments had to be done before the post-experiment. Cages in which the trial pheasants lived were disinfected before every experiment preventing the specimens from being sick. There were plenty of favorite foods for Elliot's pheasants.

\section{Methods}

The energy balance of Elliot's pheasant was measured by the daily collection of the trial pheasants' excrement (Zhang et al, 2004). During the experiment, the birds were kept alone in a cage that consisted of an inner and outer room. The inner room $(1.9 \mathrm{~m} \times 2.8 \mathrm{~m})$ was used for feeding and rest, with one food manger hanging on the wall about $10 \mathrm{~cm}$ off the ground. The outer room $(3.5 \mathrm{~m} \times 2.8 \mathrm{~m})$ was used for movement, and the walls and nets of outer room were $1.25 \mathrm{~m}$ and $0.7 \mathrm{~m}$ height, respectively. The cage grounds were covered with double films. There were a variety of flowers and trees around the cage and the environment was very quiet. In order to make the trial pheasants adapt separate feeding, the preexperiment was 8 days, then, the post-experiment was 6 days. All the Elliot's pheasants were weighed hungrily with electronic scales before and after each experiment.

The foods of Elliot's pheasant consisted of dried corns and compound forages, which were put in the food manger, and cabbages were hung on the wall with a thin wire. The trial pheasants were fed 2 times, at 08:00 and 13:00 each day, and their excrement and urine acid were collected 3 times with the stainless steel spoons and plastic syringes, respectively, at 08:00, 13:00 and 18:00 each day, Surplus baits were collected at 18:00 each day, The food intake of every bird was weighed and calculated with the Pallet scales each day. All the collective excreta samples were mixed, signed and placed in the Petri dish, then, kept in the vacuum oven at a constant heat of $65{ }^{\circ} \mathrm{C}$ for $3-4$ days. The cabbages were also hung around the cage to correct the evaporation of cage's cabbages. According to the actual situation of Guilin's climate, the experiment times can be divided into spring (March-May), summer (June-August), autumn (September-November) and winter (December-February), and the temperatures of spring, summer, autumn and winter were 20.3, 28.0, 18.6 and $8.1{ }^{\circ} \mathrm{C}$, respectively. Energy metabolism experiments were made every month under the natural temperature. Lastly, we took the average temperature between maximum and minimum as the day temperature and the average of 6 days formal experiments as trial temperature. From January. to December in the whole year, there were 12 groups' of temperatures were measured, which were $7.2,5.0,14.5,22.0,24.5,26.5$, 28.0, 29.6, 25.2, 18.5, 12.0 and $9.0{ }^{\circ} \mathrm{C}$.

Many studies have shown there were no sex difference between food intake and excreta, and accordingly we did not take the sex difference into consideration during this experiment (Kendengh, 1970; Wang et al, 1996).

The food digestibility (\%) was calculated by using the following formula: $D=(E i-E e) / E i$, in which $\mathrm{D}$ is food digestibility (\%), Ei is gross energy intake, Ee is excrement energy. The calorific values of corns, compound forages and Chinese cabbages were measured 
with GR-3500 oxygen bomb calorimeter (Changsha Instruments).

\section{Body weight}

The body weight of trial pheasants were measured with the electronic scales precise to $0.1 \mathrm{~g}$. After Elliot's pheasant nestlings were hatched by machine in May 2010 and their feather dried, their body mass were measured and regarded as 0d index; 1-30 days old nestlings body mass was recorded daily; $31 \pm$ days body masses were recorded once every 2 days, $46 \pm$ days old were recorded once every 3 days, $55 \pm$ days old were recorded once every 5 days, $70 \pm$ days old were recorded once every 10 days, until nestlings reached 100 days old. The body mass of the 4-year old adults were measured monthly, before and after the formal experiment, when the specimens were hungry.

\section{Data analysis}

Data were analyzed by using the SPSS11.5 statistical package. All results were calculated by oneway ANOVA and expressed as mean $\pm S E$. The differences of the same years' groups among different seasons were analyzed by post hoc multiple comparisons ANOVA, and the differences of the same seasons among different years' groups were analyzed using paired $t$-Test, with $(P<0.05)$ taken as statistically significant.

\section{RESULTS}

Gross energy intake, metabolic energy and food digestibility
Season gross intake, metabolic energy and food digestibility of Elliot's pheasant were analyzed by using post hoc multiple comparisons ANOVA and paired $t$-Test (Table 1, Figure 1, Table 2, Figure 2), respectively. The results showed that there were significant differences among the gross energy intake of Elliot's pheasant (4year adults: $F=9.470, P=0.000<0.05, n=72$; 1 -years nonages: $F=9.427, P=0.000<0.05, n=72$ ), and that the gross energy intake and metabolic energy were highest in winter and lowest in summer. In the same season, the gross energy intake of 1-year nonages was greater than for 4-year adults except spring $(t=2.472, d f=71, P=0.016<0.05$, Table 1, Table 2). Likewise the metabolic energy of 1years nonages was also larger than 4-year adults except for during spring $(t=1.940, d f=71, P=0.046<0.05$, Table 1, Table 2). The average food digestibility (\%) of 4-year adults and 1-years nonages were $(85.44 \pm 0.54) \%$ and $(84.14 \pm 0.55) \%$, respectively, indicting that the food digestibility (\%) of 4-year adults was better than that of 1 -years nonages $(t=6.159, d f=71, P=0.000<0.05)$. With the temperature increase, the gross energy intake, metabolic energy and food digestibility of the different age groups of Elliot's pheasants lowered all 12 moths of the year (Table 3, Table 4). The $29.6{ }^{\circ} \mathrm{C}$ in August was the highest temperature and the metabolic energy was the smallest, while the $5.0^{\circ} \mathrm{C}$ of February was the lowest temperature and the metabolic energy was largest over the entire year.

\section{Excreta, excrement energy and excrement calorific} value

The excreta, excrement energy and excrement

Table 1 Seasonal energy intake of 4-year adults

\begin{tabular}{|c|c|c|c|c|c|c|c|}
\hline & Spring & Summer & Autumn & Winter & $n$ & $F$ & $P$ \\
\hline Food intake $(\mathrm{g} / \mathrm{d})$ & $22.7 \pm 1.3^{\mathrm{a}}$ & $19.1 \pm 1.3^{b}$ & $26.4 \pm 3.4^{\mathrm{c}}$ & $28.8 \pm 2.3^{c}$ & 72 & 17.675 & 0.000 \\
\hline Gross energy intake $(\mathrm{kJ} / \mathrm{d})$ & $362.39 \pm 14.81^{\mathrm{a}}$ & $305.36 \pm 13.64^{\mathrm{a}}$ & $429.09 \pm 29.80^{b}$ & $462.11 \pm 27.74^{c}$ & 72 & 9.470 & 0.000 \\
\hline Excreta $(\mathrm{g} / \mathrm{d})$ & 4. $31 \pm 0.62^{\mathrm{a}}$ & $3.32 \pm 0.60^{\mathrm{b}}$ & $5.36 \pm 0.69^{\mathrm{c}}$ & 4. $49 \pm 0.41^{\mathrm{a}}$ & 72 & 27.279 & 0.000 \\
\hline Excrement energy $(\mathrm{kJ} / \mathrm{d})$ & $56.45 \pm 2.05^{\mathrm{a}}$ & $41.69 \pm 2.13^{b}$ & $71.86 \pm 4.45^{\mathrm{c}}$ & $58.77 \pm 2.85^{\mathrm{a}}$ & 72 & 16.673 & 0.000 \\
\hline Metabolic energy $(\mathrm{kJ} / \mathrm{d})$ & $305.77 \pm 13.40^{\mathrm{a}}$ & $263.67 \pm 11.89^{\mathrm{a}}$ & $357.23 \pm 25.49^{\mathrm{a}}$ & $403.12 \pm 24.91^{b}$ & 72 & 9.287 & 0.000 \\
\hline Food digestibility (\%) & $84.13 \pm 1.78^{\mathrm{a}}$ & $86.92 \pm 0.73^{b}$ & $83.34 \pm 0.56^{\mathrm{c}}$ & $87.09 \pm 0.75^{b}$ & 72 & 49.258 & 0.000 \\
\hline
\end{tabular}

Data of Table 1 were analyzed by using post hoc multiple comparisons ANOVA. Data with different lowercase letters in a row are regarded as significant or very significant differences $(P<0.05)$.

Table 2 Seasonal energy intake of 1-years nonages

\begin{tabular}{|c|c|c|c|c|c|c|c|}
\hline & Spring & Summer & Autumn & Winter & $n$ & $F$ & $P$ \\
\hline Food intake (g/d) & $24.4 \pm 2.1^{\mathrm{a}}$ & $20.9 \pm 1.9^{a}$ & $30.3 \pm 3.5^{b}$ & $30.6 \pm 2.7^{b}$ & 72 & 9.943 & 0.000 \\
\hline Gross energy intake $(\mathrm{kJ} / \mathrm{d})$ & $337.86 \pm 19.02^{a}$ & $335.60 \pm 17.99^{\mathrm{a}}$ & $486.14 \pm 36.50^{b}$ & $492.79 \pm 35.85^{b}$ & 72 & 9.427 & 0.000 \\
\hline Excreta $(\mathrm{g} / \mathrm{d})$ & 4. $21 \pm 0.12^{\mathrm{a}}$ & 4. $11 \pm 0.28^{\mathrm{a}}$ & $6.16 \pm 0.12^{b}$ & $5.69 \pm 0.46^{\mathrm{b}}$ & 72 & 23.562 & 0.000 \\
\hline Excrement energy $(\mathrm{kJ} / \mathrm{d})$ & $52.97 \pm 2.04^{\mathrm{a}}$ & $50.94 \pm 2.87^{\mathrm{a}}$ & $82.81 \pm 5.40^{b}$ & $72.49 \pm 4.07^{\mathrm{c}}$ & 72 & 37.491 & 0.000 \\
\hline Metabolic energy $(\mathrm{kJ} / \mathrm{d})$ & $284.86 \pm 17.22^{\mathrm{a}}$ & $284.66 \pm 15.16^{\mathrm{a}}$ & $402.26 \pm 31.46^{b}$ & $420.30 \pm 31.98^{b}$ & 72 & 8.520 & 0.000 \\
\hline Food digestibility (\%) & $83.80 \pm 1.34^{\mathrm{a}}$ & $84.79 \pm 0.43^{b}$ & $82.76 \pm 1.63^{\mathrm{c}}$ & $84.83 \pm 0.43^{b}$ & 72 & 3.563 & 0.000 \\
\hline
\end{tabular}

The data of Table 2 were analyzed by using post hoc multiple comparisons ANOVA. Data with different lowercases letters in a row is regarded as significant or very significant differences $(P<0.05)$. 


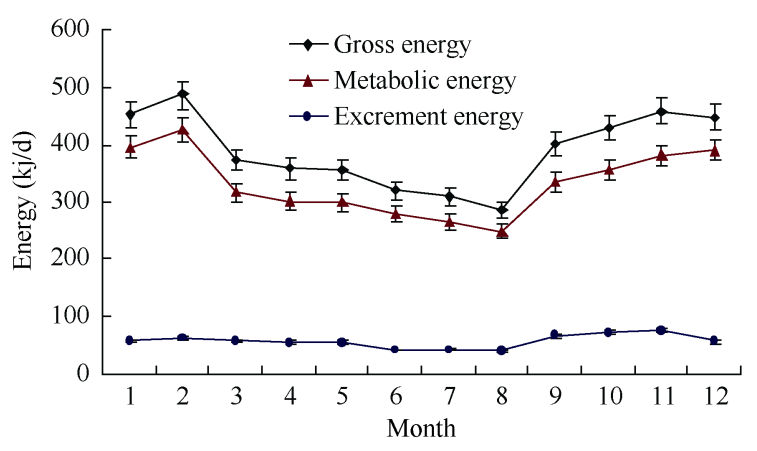

Figure 1 Monthly change in the energy intake of 4-year adults

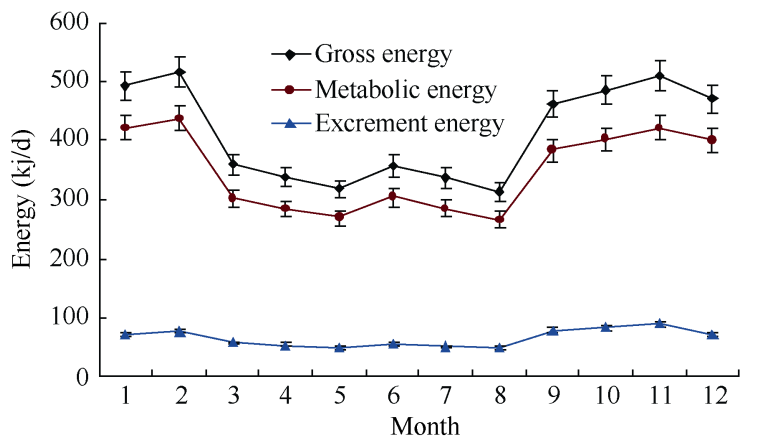

Figure 2 Monthly change in the energy intake of 1-year nonages

Table 3 Monthly energy intake of 4-year adults

\begin{tabular}{ccccc}
\hline Month & $\begin{array}{c}\text { Temperature } \\
\left.{ }^{\circ} \mathrm{C}\right)\end{array}$ & $\begin{array}{c}\text { Cross energy } \\
(\mathrm{kJ} / \mathrm{d})\end{array}$ & $\begin{array}{c}\text { Metabolic } \\
\text { energy }(\mathrm{kJ} / \mathrm{d})\end{array}$ & $\begin{array}{c}\text { Excrement } \\
\text { energy }(\mathrm{kJ} / \mathrm{d})\end{array}$ \\
\hline 1 & 7.2 & $452.74 \pm 49.04^{\mathrm{a}}$ & $395.15 \pm 44.17^{\mathrm{a}}$ & $57.59 \pm 4.94^{\mathrm{a}}$ \\
2 & 5.0 & $486.54 \pm 53.34^{\mathrm{a}}$ & $424.60 \pm 47.82^{\mathrm{a}}$ & $61.94 \pm 5.58^{\mathrm{a}}$ \\
3 & 14.5 & $373.88 \pm 26.82^{\mathrm{b}}$ & $315.32 \pm 24.29^{\mathrm{b}}$ & $58.56 \pm 2.87^{\mathrm{a}}$ \\
4 & 22.0 & $357.80 \pm 31.21^{\mathrm{b}}$ & $302.29 \pm 28.05^{\mathrm{b}}$ & $55.51 \pm 3.57^{\mathrm{a}}$ \\
5 & 24.5 & $355.50 \pm 22.42^{\mathrm{b}}$ & $299.70 \pm 26.64^{\mathrm{b}}$ & $55.30 \pm 4.54^{\mathrm{a}}$ \\
6 & 26.5 & $323.59 \pm 23.93^{\mathrm{b}}$ & $280.99 \pm 20.68^{\mathrm{b}}$ & $42.60 \pm 3.29^{\mathrm{b}}$ \\
7 & 28.0 & $308.69 \pm 25.03^{\mathrm{b}}$ & $264.86 \pm 22.23^{\mathrm{b}}$ & $43.84 \pm 4.17^{\mathrm{b}}$ \\
8 & 29.6 & $287.13 \pm 25.96^{\mathrm{b}}$ & $247.65 \pm 21.81^{\mathrm{b}}$ & $39.48 \pm 4.47^{\mathrm{b}}$ \\
9 & 25.2 & $401.85 \pm 55.15^{\mathrm{a}}$ & $334.82 \pm 46.90^{\mathrm{a}}$ & $67.03 \pm 8.27^{\mathrm{a}}$ \\
10 & 18.5 & $429.08 \pm 54.54^{\mathrm{a}}$ & $356.34 \pm 46.92^{\mathrm{a}}$ & $72.73 \pm 8.26^{\mathrm{a}}$ \\
11 & 12.0 & $457.04 \pm 52.69^{\mathrm{a}}$ & $380.70 \pm 44.97^{\mathrm{a}}$ & $76.34 \pm 7.75^{\mathrm{a}}$ \\
12 & 9.0 & $446.39 \pm 48.67^{\mathrm{a}}$ & $389.61 \pm 43.77^{\mathrm{a}}$ & $56.78 \pm 4.91^{\mathrm{a}}$
\end{tabular}

The data of Table 3 were analyzed by using post hoc multiple comparisons ANOVA. Data with different lowercases letters in a row is regarded as significant or very significant differences $(P<0.05)$

calorific values of Elliot's pheasant were analyzed using post hoc multiple comparisons ANOVA and paired $t$-Test. The results indicated there were significant differences for the excreta (4-year adults: $F=72.279, P=0.000(0.05$, $n=72$; 1 -years nonages: $F=23.562, P=0.000<0.05, n=72)$, and excrement energy (4-year adults: $F=16.673, P=$ $0.000<0.05, n=72 ; 1$-year nonages: $F=97.491, P=$ $0.000<0.05, n=72$ ). Of Elliot's pheasant in the same age,
Table 4 Monthly energy intake of 1-year nonages

\begin{tabular}{ccccc}
\hline Month & $\begin{array}{c}\text { Temperatur } \\
\mathrm{e}\left({ }^{\circ} \mathrm{C}\right)\end{array}$ & $\begin{array}{c}\text { Cross energy } \\
(\mathrm{kJ} / \mathrm{d})\end{array}$ & $\begin{array}{c}\text { Metabolic } \\
\text { energy }(\mathrm{kJ} / \mathrm{d})\end{array}$ & $\begin{array}{c}\text { Excrement } \\
\text { energy }(\mathrm{kJ} / \mathrm{d})\end{array}$ \\
\hline 1 & 7.2 & $492.78 \pm 65.49^{\mathrm{a}}$ & $421.96 \pm 59.76^{\mathrm{a}}$ & $70.82 \pm 6.27^{\mathrm{a}}$ \\
2 & 5.0 & $514.90 \pm 62.83^{\mathrm{a}}$ & $438.27 \pm 55.58^{\mathrm{a}}$ & $76.63 \pm 7.42^{\mathrm{a}}$ \\
3 & 14.5 & $358.52 \pm 34.41^{\mathrm{b}}$ & $301.27 \pm 31.42^{\mathrm{b}}$ & $57.25 \pm 3.39^{\mathrm{a}}$ \\
4 & 22.0 & $337.85 \pm 34.92^{\mathrm{b}}$ & $284.08 \pm 31.46^{\mathrm{b}}$ & $53.78 \pm 3.77^{\mathrm{b}}$ \\
5 & 24.5 & $317.20 \pm 33.39^{\mathrm{b}}$ & $269.25 \pm 30.77^{\mathrm{b}}$ & $47.95 \pm 2.79^{\mathrm{b}}$ \\
6 & 26.5 & $357.49 \pm 32.64^{\mathrm{b}}$ & $303.47 \pm 27.45^{\mathrm{b}}$ & $54.03 \pm 5.21^{\mathrm{b}}$ \\
7 & 28.0 & $335.60 \pm 32.17^{\mathrm{b}}$ & $284.66 \pm 27.33^{\mathrm{b}}$ & $50.94 \pm 5.03^{\mathrm{b}}$ \\
8 & 29.6 & $313.71 \pm 31.77^{\mathrm{b}}$ & $265.86 \pm 26.53^{\mathrm{b}}$ & $47.85 \pm 5.24^{\mathrm{b}}$ \\
9 & 25.2 & $462.24 \pm 66.13^{\mathrm{a}}$ & $384.45 \pm 57.09^{\mathrm{a}}$ & $77.79 \pm 9.08^{\mathrm{a}}$ \\
10 & 18.5 & $486.11 \pm 66.91^{\mathrm{a}}$ & $402.15 \pm 58.07^{\mathrm{a}}$ & $82.28 \pm 10.62^{\mathrm{a}}$ \\
11 & 12.0 & $510.06 \pm 67.18^{\mathrm{a}}$ & $421.69 \pm 57.66^{\mathrm{a}}$ & $88.38 \pm 9.53^{\mathrm{a}}$ \\
12 & 9.0 & $470.69 \pm 68.40^{\mathrm{a}}$ & $400.68 \pm 60.24^{\mathrm{a}}$ & $70.02 \pm 8.31^{\mathrm{a}}$ \\
\hline
\end{tabular}

Data of Table 4 were analyzed by using post hoc multiple comparisons ANOVA. Data with different lowercases letters in a row is regarded as significant or very significant differences $(P<0.05)$.

the excreta was highest in autumn and lowest in summer. During the same season, the excreta of 4-year adults were smaller than 1 -year nonages $(t=6.517, d f=71$, $P=0.000<0.05$, Table 1, Table 2). There were no significant differences among the excrement calorific values of the 4-year adults $(t=1.024, d f=71, P=0.453>$ $0.05, n=72)$, and nonages were also no significant differences $(t=1.483, d f=71, P=0.429>0.05, n=72)$.

\section{Body weight}

The body weight of Elliot's pheasant nestling was analyzed by using post hoc multiple comparisons ANOVA. The results (Table 5, Figure 3 ) showed that the

Table 5 Body weight and average daily increase of body mass of nestlings

\begin{tabular}{cccc}
\hline Day & Body weight/g & Day & $\begin{array}{c}\text { Average daily } \\
\text { increase } / g\end{array}$ \\
\hline 1 & $21.64 \pm 0.54^{\mathrm{a}}$ & $1-10$ & $0.66 \pm 0.02^{\mathrm{a}}$ \\
10 & $28.25 \pm 0.58^{\mathrm{b}}$ & $11-20$ & $1.07 \pm 0.01^{\mathrm{b}}$ \\
20 & $38.94 \pm 0.56^{\mathrm{c}}$ & $21-30$ & $1.59 \pm 0.03^{\mathrm{c}}$ \\
30 & $54.86 \pm 0.24^{\mathrm{d}}$ & $31-40$ & $1.74 \pm 0.04^{\mathrm{d}}$ \\
40 & $72.30 \pm 0.25^{\mathrm{e}}$ & $41-50$ & $5.99 \pm 0.06^{\mathrm{e}}$ \\
50 & $132.2 \pm 0.42^{\mathrm{f}}$ & $51-60$ & $4.24 \pm 0.01^{\mathrm{f}}$ \\
60 & $174.59 \pm 0.42^{\mathrm{g}}$ & $61-70$ & $7.88 \pm 0.03^{\mathrm{g}}$ \\
70 & $253.56 \pm 0.58^{\mathrm{h}}$ & $71-80$ & $2.09 \pm 0.02^{\mathrm{h}}$ \\
80 & $274.41 \pm 0.48^{\mathrm{i}}$ & $81-90$ & $6.32 \pm 0.22^{\mathrm{i}}$ \\
90 & $337.56 \pm 2.68^{\mathrm{j}}$ & $91-100$ & $7.12 \pm 0.38^{\mathrm{j}}$ \\
100 & $408.76 \pm 6.48^{\mathrm{k}}$ & $1-100$ & $3.50 \pm 0.33^{\mathrm{m}}$ \\
$P$ & 0.000 & $P$ & 0.000 \\
\hline
\end{tabular}

Data of Table 5 were analyzed using post hoc multiple comparisons ANOVA. Data with different lowercases letters in a row is regarded as significant or very significant differences $(P<0.05)$. 


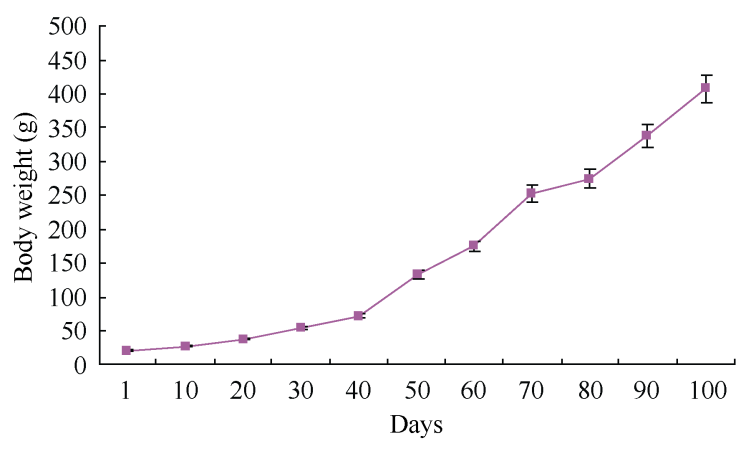

Figure 3 Daily change of nestling body weight

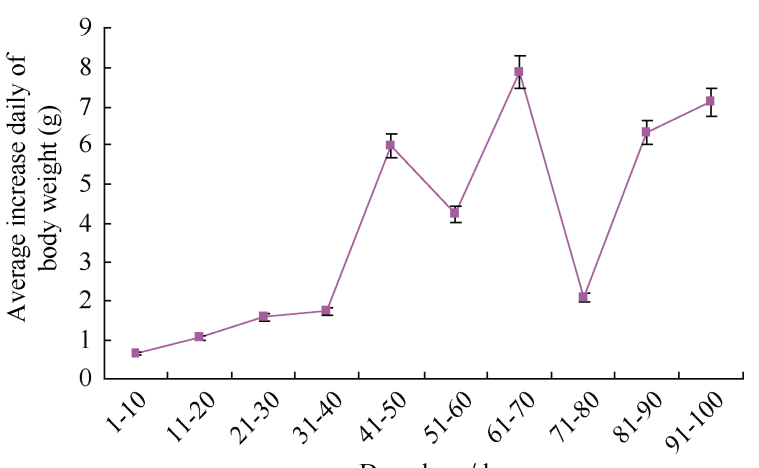

Day phase/d

Figure 4 Average daily increase of nestling body mass

average body mass was $22.34 \pm 1.69 \mathrm{~g}$ at the hatching and the average daily increase of body mass was $7.88 \pm 0.03 \mathrm{~g}$, which was the maximum when the nestling was $60-70$ days old. The 100 day old nestling was $408.76 \pm 6.48 \mathrm{~g}$, close to its adult body mass. After 100 days, the average daily increase of body weight decreased and the body weight gained slowly (Figure 4). The Syrmaticus ellioti nestling was close to 300 days when energy intake experiments were measured; each seasonal body weight had no change before and after the formal experiments: $910.80 \pm 39.40 \mathrm{~g}, 925.00 \pm 53.40 \mathrm{~g}, 938.00 \pm 33.60 \mathrm{~g}$ and $941.20 \pm 20.20 \mathrm{~g}$, for spring, summer, fall and winter respectively. Each season the body weight of 4-year adults also had no change before and after the formal experiments: $1029.30 \pm 46.60 \mathrm{~g}, 1017.50 \pm 50.26 \mathrm{~g}$, $1012.40 \pm 42.50 \mathrm{~g}$ and $1021.90 \pm 30.00 \mathrm{~g}$, for spring, summer, fall and winter, respectively.

\section{DISCUSSIONS}

\section{Food and food digestibility}

The analysis of energy balance of Elliot's pheasant was established on conditions of natural light and cage situations in four different seasons. The foods afforded to the specimens were corns, compound forages and cabbages whose nutrition was very rich, and there was no significant difference for the individual body weight of birds before and after the experiment. Comparing the study results (Table 1, Table 2) with previously reported results of wild birds' energy metabolism, the food digestibility of Elliot's pheasant is lower than bird eating seeds. This may be one of the reasons that the foods afforded were given artificially and the study of diet selection of Elliot's pheasant have not been previously done. A further study is needed to determine that the impact of variation wild diet of Elliot's pheasant on its food digestibility. The energy metabolism levels of birds can also be affected by their activity (Freckleton et al, 2002). As the trial pheasants exercised in a limited spatial cage, their energy metabolism level were slightly lower than wild bird eating seeds in the natural conditions, but higher than that of the Common Pheasant Phasianus cochicus (79.8\%), as reported by Wang et al (2003).

Impact of environment temperature on energy intake

Energy metabolism maintains existence when the birds' weight remains constant, thus the metabolic energy is equal to survival energy (Kendeigh, 1975). With increased temperature, the gross energy intake and metabolic energy of Elliot's pheasant declined (Table 1, Table 2) consistent with earlier findings (Olson \& Kendeigh, 1980; Zhang et al, 1998). Climate is one of the most important factors that determine individual energy consumption level of species and interspecies (Canterbury, 2002). Here, we showed that the gross energy intake, metabolic energy and excrement energy varied monthly and decreased as temperature increased. At $29.6{ }^{\circ} \mathrm{C}$ August had the highest temperature and the metabolic energy was the lowest, while the $5.0{ }^{\circ} \mathrm{C}$ of February was the lowest temperature and the metabolic energy was highest for the entire year. With the decreasing temperature, food digestibility decreased, and this is the reason for the increase of gross food consumption at hypothermia. To maintain the birds' energy balance as the temperature increases, the excrement energy decreased, and food digestibility is increases. The energy metabolism level of the birds directly reflects their tolerance at the low ambient temperature; the populations' highly metabolic capacity is more adaptable to the cold environment (Likenes \& Swanson, 1996; Swanson, 1995). Our study showed that the food digestibility was the highest in winter, perhaps as an adaptive response to the colder temperatures.

\section{Analysis of excreta, excrement energy and excrement calorific value}

In the same age, there were significant seasonal differences for the excreta (4-year adults: $F=72.279$, $P=0.000<0.05, n=72$; 1 -years nonages: $F=23.562$, $P=0.000<0.05, n=72)$ and excrement energy of Elliot's pheasants (4-year adults: $F=16.673, P=0.000<0.05$, $n=72$; 1 -year nonages: $F=97.491, P=0.000<0.05, n=72$ ). Excreta were the largest in autumn, but in summer the 
smallest. Altering the form of digestive tract or widen the volume of It may be an adaptive response to alter the form of digestive tract or widen the volume of it (Gross et al, 1985), and the adaptive capacity of the bowel determines the maximum rate of food digestibility (Kooyman et al, 1992) may be adaptive responses. In the same season, the excreta of 4-year adults were smaller than that of 1-year old nonages (Table 1, Table 2). This may be relative to the diversity of the structure of digestive tract. Elliot's pheasant can tolerate the cold in winter and adapt to the environment by decreasing excreta, thereby increasing energy digestibility. There were no significant differences among the excrement calorific values of Elliot's pheasant, but the trend of decreasing as temperature increased is in accordance with Wang's (1996) earlier findings.

\section{Impact of body weight and age on energy digestibility}

The energy metabolism level of bird depends on their body weight (McNb, 2000). There were 2 groups of Elliot's pheasants (4-year adults and 1-year nonages) in this experiment. The average body weight of 100 days old nestling hatched in May 2010 was $408.76 \pm 6.48 \mathrm{~g}$, close to adult body weight. After 100 days, the average daily increase of body weight decreased and the body weight grew slowly (Figure 4). When nestling were 300 days old, each seasonal body mass had no change before and after the formal experiments; $910.80 \pm 39.40 \mathrm{~g}$, $925.00 \pm 53.40 \mathrm{~g}, 938.00 \pm 33.60 \mathrm{~g}$ and $941.20 \pm 20.20 \mathrm{~g}$, in spring, summer, fall and winter, respectively. The average body weights of 4-year adults in spring, summer, fall and winter were $1029.30 \pm 46.60 \mathrm{~g}, 1021.90 \pm 30.00 \mathrm{~g}$, $1017.50 \pm 50.26 \mathrm{~g}$ and $1012.40 \pm 42.50 \mathrm{~g}$, respectively. In the same season, the energy digestibility of 4-year adults was stronger than 1-years nonages, as digestibility may be affected by body weight.

The Elliot's pheasants hatched in May 2010, less than one year old, are in the growth and development phase but tend to slow as they age, and their average body weights were less than that of the 4-year old adults. The large individual animals have relatively small body surface areas, and heat loss of per unit body weight is relatively less in winter; however, in the conditions of

\section{References}

Baillie JEM, Hilton-Taylor C, Stuart SN. 2004. 2004IUCN Red List of Threatened Species: A Globe Species Assessment. Switzerland: IUCN.

Cai LY, Xu YP, Jiang PP, Ding P, Yao XH, Xu XR, Wang GB. 2007. Home range and daily moving distance of Elliot's Pheasant. J Zhejiang Univ: Sci Ed, 34(6): 679-683.

Canterbury G. 2002. Metabolic adaptation and climatic constraints on winter bird distribution. J Evolution, 83(4): 946-957. high temperature during summer, the heat of environment flow into animal's body is relatively small (Luo et al, 2008), so the needs of gross metabolic energy of the per unit time per unit body weight of Elliot's pheasant is less, and energy digestibility is stronger. The results indicate that the heavier birds had stronger food digestibility, in accordance with research done on the Mountain Finch Leucosticte brandti (Qian et al, 1983). We also discovered that female Elliot's pheasant in the 4-year adults group had a higher average metabolic energy than the males per day, but their body weight was lower than the males. The reasons for this discrepancy were that the female Elliot's pheasant of 4-year adults had to accumulate more adipose than males for reproducing in next year, and the female bird in a semi-domesticated state can maintain spawning for a relatively longer time by redistributing nutrients in their body (Zhang \& Yang, 2005), so the use of individual additional energy is concerned with the increase of total adipose (Wise \& Weight, 1994).

From the above analysis, we can infer that there is significant difference between the gross energy intake, excrement energy, metabolic energy and temperature of different age groups of Elliot's pheasant. At the same time, body weight and age most certainly impact food digestibility during the same season, food digestibility was higher in of 4-year adults than in 1-year nonages. Zhou (1990) reported that the food digestibility of wild birds taken seeds or nuts were $(89.5 \% \pm 4.7) \%$. Our results showed that the average food digestibility $(\%)$ of 4 -year adults and juveniles were $(85.44 \pm 0.54) \%$ and $(84.14 \pm 0.55) \%$, respectively. Elliot's pheasant mainly eat plant leaves, stems, buds, flowers, fruits, seeds and other plant food crops; it also eats insects and other animal food (John et al, 2000). The metabolic energy of the two groups of trial pheasant were the lowest in August (29.6 ${ }^{\circ} \mathrm{C}$ ), suggesting that Elliot's pheasant can better adapt to subtropical mountain environments through good food digestibility.

Acknowledgements: We are grateful to Professor JinSong LIU of Wenzhou University for providing valuable suggestions and references during this experiment.

Delacour J. 1977. The Pheasants of the World. 2nd ed. Hindhead: World Pheasants Association and Spur Publications.

Ding P. 1998. The distributions and systematic analysis of the longtailed pheasants. Life Sci Res, 2(2): 122-131.

Ding P, Zhu GY. 1988. The ecology of Symaticus elliot Swinhoe. Acta Ecol Sin, 8(1): 44-50.

Ding P, Zhu GY, 1989. The Elliot's pheasant. Chn J Zool, 24(2): 39-42. 
Ding P, Jiang SR, Zhu GY. 2000. The study on fragmentation of habitat used by Elliot's pheasant in Western Zhejiang. Zool Res, 21(1): 65-69.

Ding P, Yang YW, Liang W, Jiang SR, Zhang Y. 1996. The habitat of Elliot's pheasant in the Leigong Mountain Nature Reserve. Acta zool Sin, 42(Supplenment): 62-68.

Ding P, Yang YW, Li Z, Jiang SR, Zhuge Y. 2001. Vegetation characteristics of habitats used by Elliot's pheasant. $J$ Zhejiang Univ: Sci Ed, 28(5): 557-562.

Freckleton RP, Harvey PH, Pagel MD. 2002. Phylogenetic analysis and comparative data: A test and review of evidence. Am Nat, 160(6): 712726.

Gross JE, Wang ZW, Wunder BA. 1985. Effects of food quality and energy needs: changes in gut morphology and capacity of Microtus ochrogaster. J Mamm, 66(4): 661-667.

Jiang PP, Fang SG, Ding P. 2005a.An application of control region sequence as a matrilineage marker for Elliot's Pheasant of a zoo population. Anim Biotechnol, 16(1): 11-15.

Jiang PP, Ge YF, Lang QL, Ding P. 2007. Genetic structure among wild populations of Elliot's Pheasant Syrmaticus ellioti in China from mitochondrial DNA analyses. Bird Conserv Int, 17: 177-185.

Jiang PP, Lang QL, Fang SG, Ding P, Chen LM. 2005b. A genetic diversity comparison between captive individuals and wild individuals of Elliot's Pheasants (Syrmaticus ellioti) using mitochondrial DNA. $J$ Zhejiang Univ: Sci B, 6(5): 413-417.

John M, Karen P, He FQ. 2000. A Field Guide to the Birds of China. Oxford University Press, 35: 15-30.

Kendeigh SC. 1970. Energy requirements for existence in relation to size of bird. Condor, 72: 60-65.

Kendeigh SC. 1975. Measurement of existence energy in granivorous birds //Grodziński W, Klekowski RZ, Duncan A. Methods for Ecological Bioenergetics. Oxford: Blackwell Scientific Publications, 24: 341-345.

Kooyman GL, Cherel Y, LeMaho Y, Croxall JP, Thorson PH, Ridoux V, Kooyman CA. 1992. Diving behavior and energetics during foraging cycles in King Penguins. Ecol Monogr, 62(1): 143-162.

Li BH. 1985. Elliot's pheasant in Southern Anhui Province. Wild Life, (5): $8-20$.

Long DZ. 1985.Ecology of Elliot's pheasant, Wild life, (1): 24-25.

Li XT. 1996. The Gamebirds of China: Their Distribution and status. Beijing: International Academic Publishers.

Likenes ET, Swanson DL. 1996. Seasonal variation in cold tolerance, basal metabolic rate, and maximal capacity for thermogenesis in white breasted nuthatches Sitta carolensis and downy woodpechers Picoides pucescens, two unrelated arboreal temperate residents. J Avian Biol, 27(4): 279-288
Long DZ. 1985. Ecology of Elliot's pheasant. Wild Life, (1): 24-25.

Lu TC. 1991. A Rare and Endangered Birds of China. Fujian: Fujian Science and Technology Publishers, 314-327.

Luo Y, Yu TL, Li HH, Pang YT, Chen Y. 2007.Comparison of energy metabolism between Syrmaticus ellioti and Syrmaticus humiae in captivity in winter. Sichuan J Zool, 26(1): 145-151.

Luo Y, Yu TL, Huang CM, Zhao T, Li HH, Li CJ. 2011. Metabolism and thermoregulation between Mrs Hume's Pheasant (Syrmaticus humiae) and Elliot's Pheasant (S. ellioti). Zool Res, 32(4): 396-402.

$\mathrm{McNb}$ BK. 2000. The influence of body mass, climate, and distribution on the energetic of south pacific pigeons. J Comp Biochem Physiol A, 127(3): 309-329.

Olson JB, Kendeigh SC. 1980. Effect of season on the energetics, body composition, and cage activity of the Field Sparrow. Auk, 97: 704-720.

Qian GZ, Zhang XA, Ye QZ. 1983. Effect of temperature on energy balance of the Mountain Finch. Acta Ecol Sin, 3(2): 157-163.

Shi JB, Zheng GM. 1997. The seasonal changes of habitats of Elliot's Pheasant. Zool Res, 18(3): 275-283.

Swanson DL. 1995. Seasonal variation in thermogenic capacity of migratory warbling vireos. Auk, 112(4): 870-877.

Wang F, He YL, Gao ZG, Cui SH. 2003. Study on metabolic parameters and energy requirement of pheasants during laying period. Chinese $J$ Anim Nutri, 15(4): 23-27.

Wang XH, Gao W, Tian Y, Xiang GQ. 1996. Energy metabolism of Hazeal Grouse (Bonasa bonasia) raised in captivity. Acta Zool Sin, 42(S1): 152-154.

Wise DR, Weight C. 1994. Composition and reproductive performance of pheasants (Phasianus colchicus) fed restricted or unrestricted diets. Res Vet Sci, 57(1): 119-124.

Xu YP, Zheng JW, Ding P, Jiang PP, Cai LY, Huang XF, Yao XH, Xu XR, Yu ZP. 2007. Seasonal change in ranging of Elliot's pheasant and its determining factors in Guanshan national nature reserve, Jiangxi. Biodiver Sci, 15(4): 337-343.

Zhang LQ, Yang ZC. 2005. Energy budget and feed intake of Golden pheasant in autumn reproductive period. Sichuan J Zool, 24(4): 463465 .

Zhang LQ, Yang ZC, Li CQ, Sun RY. 1998. Study on the energy balance of caged Black Grouse (Lyrurus terix baikallensis). J Beijing Normal univ: Nat Sci, 34(3): 399-402.

Zhang TZ, Liu WS, Wu WY, Su JP. 2004. Energy metabolism and protein deposit volume of Great Bustard in growth period. Chin J Appl Environ Biol, 10(1): 116-118.

Zou XH. 1990. Wildliffe Nutrition. Haerbin: Northeast Forestry University Publishers. 